A Guide to Radiation Protection 


\section{A Guide to Radiation Protection}

\section{J. Craig Robertson}

Dept. of Physics, Dundee College of Technology, Dundee, Scotland

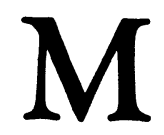


ISBN 978-1-349-02850-4 ISBN 978-1-349-02848-1 (eBook)

DOI 10.1007/978-1-349-02848-1

(C) J. Craig Robertson 1976

Softcover reprint of the hardcover 1st edition 1976 978-0-333-19278-8

All rights reserved. No part of this publication may be reproduced or transmitted, in any form or by any means, without permission

\author{
First published 1976 by \\ THE MACMILLAN PRESS LTD \\ London and Basingstoke \\ Associated companies in New York Dublin \\ Melbourne Johannesburg and Madras \\ SBN 333192788
}

This book is sold subject to the standard conditions of the Net Book Agreement 


\section{Contents}

Preface and Acknowledgements

vii

1 The biological effects of radiation 1

2 What is radioactivity? 9

3 Recognition and classification of radioactive materials 14

4 Types of radioactive source 20

5 The shielding of radiation 27

6 Radioactive decay 33

7 Radiation units 38

8 The detection and measurement of radiation 44

9 Legislation relating to the use of radioactive materials 54

10 Forewarned is forearmed 66

Appendix - Classification tables of radionuclides 75

Bibliography $\quad 82$

Index $\quad 85$ 